Original Research Paper

\title{
Detection of Methicillin-Resistant Staphylococci (MRS) and Salmonella spp. in Consumer Egg Samples
}

\author{
${ }^{1}$ Ana Claudia Lemes Pavan, ${ }^{2}$ Rafaella da Silva, ${ }^{4}$ Vanessa Kelly Capoia Vignoto, \\ ${ }^{3}$ Marcos Ferrante, ${ }^{3}$ Patrícia Marques Munhoz and ${ }^{3}$ Sheila Rezler Wosiacki \\ ${ }^{I}$ Veterinary Residence in Doenças Infecto-Contagiosas e Parasitárias, State University of Maringá (UEM), Umuarama, Brazil \\ ${ }^{2}$ Post-graduation in Produção Sustentável e Saúde Animal, State University of Maringá (UEM), Umuarama, Brazil \\ ${ }^{3}$ Department of Veterinary Medicine, State University of Maringá (UEM), Umuarama, Brazil \\ ${ }^{4}$ Department of Veterinary Medicine, Federal University of Lavras (UFL), Lavras, Brazil
}

\author{
Article history \\ Received: 14-10-2019 \\ Revised: 20-01-2020 \\ Accepted: 21-08-2020 \\ Corresponding Author: \\ Patrícia Marques Munhoz \\ Department of Veterinary \\ Medicine, State University of \\ Maringá (UEM), Umuarama, \\ Brazil \\ Email: pmmunhoz@yahoo.com.br \\ Sheila Rezler Wosiacki \\ Department of Veterinary \\ Medicine, State University of \\ Maringá (UEM), Umuarama, \\ Brazil \\ Email: srwosiacki@uem.br
}

\begin{abstract}
Despite the excellent nutritional value, the egg can be an important vehicle for bacterial infections carried by food, among them, multiresistant Staphylococci and salmonellosis. The objective of this work was to detect the presence of Methicillin-Resistant Staphylococcus spp. (MRS) and Salmonella spp. Forty dozen eggs were obtained from three free-trade fairs in the Umuarama-PR; every dozen eggs comprised a sample. They were analyzed through enrichment, selective enrichment, plating, biochemical test and specific serology for the pathogens in consumption eggs. Twenty-eight Staphylococcus spp. were isolated from 13 samples of the yolk and 8 of the eggshell, being $47.62 \%$ phenotypically characterized as Methicillin-Resistant Staphylococcus (MRS) strains. Although considered a pathogen of high importance in public health and closely related to the product in question, no bacteria of the Salmonella genus were detected in any of the samples analyzed. Staphylococci are also pathogens of significant importance within Foodborne Diseases (DTAs), requiring more epidemiological information about outbreaks involving this microorganism. Also, the rational use of antimicrobials is necessary to avoid the emergence of resistant strains.
\end{abstract}

Keywords: Staphylococci, Salmonellosis, Multidrug Resistance, Chicken, Food

\section{Introduction}

Animal production has been improved through the use of antimicrobials. However, this practice has triggered the emergence and distribution of resistant microorganisms in animal products (Téo and Oliveira, 2005).

The egg is a food of high nutritional value. However, it can carry important pathogens, such as Salmonella spp., A bacterium widely studied in poultry farming and food analysis. Also, Staphylococcus spp. that have important resistant strains, such as Methicillin-Resistant Staphylococcus spp. (MRS) moreover, it can cause extremely severe infections in humans (Oliveira and Taham, 2011; Bond and Loeffler, 2012).

Contamination of egg contents may occur in the reproductive tract of the chicken before shell formation, leading to the production of already contaminated eggs, or after laying, by factors related to the environment and egg handling (Téo and Oliveira, 2005). The poor habits of preparation and consumption of raw or undercooked eggs are one of the main factors that make this food a potential contaminant for humans (Lacerda, 2011).

In eggs, research for Staphylococcus spp. is performed in liquid dehydrated and whole eggs, where the absence of this microorganism is required in 1 gram of the product (Brasil, 1990). According to (Menezes, 2013), this requirement is justified by the fact that the egg (fresh, liquid, or dehydrated) is used as an ingredient in several foods that may not undergo heat treatment. As the egg has high nutritional value, multiplication can occur if a microbial load is present, increasing the risk to humans.

Salmonellosis is considered worldwide as one of the main zoonoses of importance for public health, characterizing endemicity, high morbidity and above all, difficulty in adopting control measures related to its spread (Shinohara et al., 2008). When present in the 
farm environment, the microorganism can infect birds and, consequently, their eggs (Braden, 2016), which may be associated with cases of foodborne infection in humans via Foodborne Diseases (Leal, 2011).

The objective was to detect the presence of Staphylococcus spp. and Salmonella spp., by conventional microbiological analysis specific for each pathogen, in eggs marketed in the free markets of the municipality of Umuarama-PR.

\section{Materials and Methods}

Forty dozen eggs were obtained from three free markets held weekly in the municipality of UmuaramaPR. The eggs were kept at room temperature for a maximum of five days since the analyses were always started on Mondays and the products were purchased on Wednesdays, Fridays and Sundays, at the several fairs visited. The analyses were presented at the facilities of the Animal Microbiology Laboratory of the State University of Maringá (UEM), Umuarama Regional Campus (CAU).

Each dozen eggs comprised one sample, totaling 40 samples analyzed. The dozens of eggs purchased met a pre-established criterion for the sanitary control involved. EGGS belonging to three categories were examined: Eggs without a sanitary inspection, eggs inspected by the Municipal Inspection Service (with the SIM seal) and eggs investigated by the Federal Inspection Service (with the SIF seal). All samples were qualitatively analyzed for the presence or absence of Staphylococcus spp. and Salmonella spp. in both yolk and shell.

The procedures were performed in a laminar flow cabin (chapel), minimizing the chances of contamination of the handled products. Initially, each egg had its surface washed in a sterile bag using $10 \mathrm{~mL}$ of $0.1 \%$ Buffered Peptone Water (APT). After this procedure, the wash liquid of the twelve eggs of the sample unit made up the sample of the shell to be processed, stored in a sterile container, corresponding to the initial preenrichment solution. It was incubated for $24 \mathrm{~h}$ at $37^{\circ} \mathrm{C}$. Then the eggs were submerged in $70 \%$ alcohol for 10 min and after that time, they were dried in the laminar flow hood under UV light. The yolks were aseptically separated and homogenized.

For the detection of Staphylococcus spp., $25 \mathrm{~mL}$ of yolk were incubated in $225 \mathrm{~mL}$ of $0.1 \%$ peptone water for $24 \mathrm{~h}$. Subsequently, nutrient agar was sown with $4.5 \% \mathrm{NaCl}$ and the results analyzed after 24 and $48 \mathrm{~h}$. Catalase, Gram stain and tube coagulase tests were also performed to characterize the bacteria. The typical colonies of Staphylococcus spp. were then seeded on Muller Hinton Agar for antimicrobial susceptibility testing with discs impregnated with penicillin, cefoxitin, oxacillin, erythromycin and clindamycin. The halos were evaluated, according to (CLSI, 2013).

For detection of Salmonella spp., after an incubation time of the pre-enrichment media, $1 \mathrm{~mL}$ of each broth (bud pool and eggshell wash pool) was transferred in 10 $\mathrm{mL}$ of Tetrationate Broth (incubated at $35^{\circ} \mathrm{C}$ for $24 \mathrm{~h}$ ) and $0.1 \mathrm{~mL}$ in $10 \mathrm{~mL}$ Rappaport-Vassiliadis Broth (incubated at $42^{\circ} \mathrm{C}$ for $24 \mathrm{~h}$ ). Samples from these selective enrichment media were then seeded in Petri dishes previously filled with XLD Agar (Xylose Lysine Deoxycholate Agar) and incubated at $35^{\circ} \mathrm{C}$ for $24 \mathrm{~h}$. Suspected colonies identified by reading the XLD plates were seeded into test tubes for biochemical analysis with the Triple Sugar and Iron Agar (TSI) and Iron Lysine Agar (ILA) (Brazil, 2003). When the growth of characteristic colonies is suspected, the pathogen was confirmed by proof of specific polyvalent rapid serum agglutination (Paiva et al., 2006).

\section{Results and Discussion}

\section{Methicillin-Resistant Staphylococci (MRS).}

Of the 40 samples analyzed, $13(32.5 \%)$ yolk and 8 (20\%) eggshell samples were characterized as positive for the presence of Staphylococcus spp. In the remaining $27(67.5 \%)$ yolk samples and $32(80 \%)$ of the shell has not detected the presence of this microorganism.

A total of 28 strains of Staphylococcus spp. were isolated from 21 yolk and shell samples. The presence of bacterial monocross growth was verified in the 13 yolk samples, being three without an inspection, 6 with municipal inspection and 4 with a federal inspection. The monocross growth was also verified in one eggshell sample without inspection and one with municipal inspection, the rest of the eggshell samples were confirmed isolation of more than one bacterial type, being two bacterial strains isolated from 2 samples with municipal inspection and three samples with federal inspection. Federally, the fourth federally-inspected eggshell samples showed growth of 3 distinct bacterial strains of Staphylococci.

In the coagulase test, only one yolk isolate was detected as Coagulase-Positive Staphylococcus spp. (CoPS), the remaining 24 strains were characterized as Coagulase-Negative Staphylococci (CoNS).

Resistance to $\beta$-lactam antibiotics was found in $53.85 \%(n=7)$ of the yolk isolates and $66.67 \%(n=10)$ of the shell (Table 1 and Fig. 1). For phenotypic characterization of MRS strains, the associated resistance between penicillin and oxacillin/cefoxitin is required, being obtained in $38.46 \%$ of the isolated strains of the bud $(n=5)$ and $66.67 \%$ of the eggshell $(n=10)$, totaling $53.57 \%(\mathrm{n}=15)($ tab. 1$)$. 


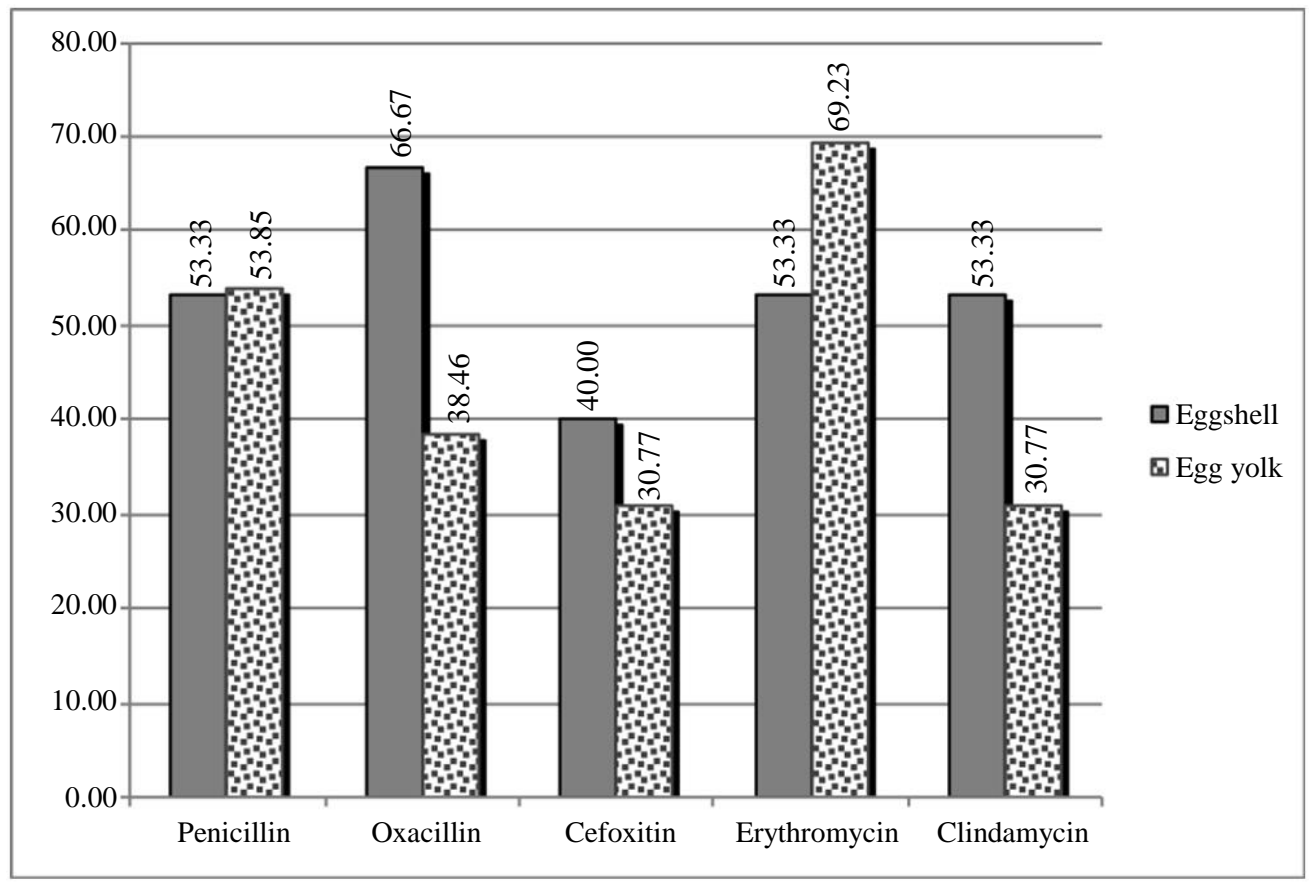

Fig. 1: Graphical representation of antibiotic resistance percentages of Staphylococcus spp. isolated from egg yolk and eggshell

Table 1: Characterization of resistance/susceptibility to $\beta$-lactams in Staphylococcus spp. isolates in Yolk and Shell in eggs of consumption in the municipality of Umuarama - PR, Brazil

\begin{tabular}{|c|c|c|c|c|c|c|}
\hline \multirow[b]{2}{*}{ Sample } & \multicolumn{6}{|c|}{ Resistant } \\
\hline & $\mathrm{P} / \mathrm{O} / \mathrm{C}$ & $\mathrm{P} / \mathrm{O}$ & $\mathrm{O}$ & $\mathrm{P}$ & Susceptible & Total \\
\hline Egg yolk & 4 & 1 & 0 & 2 & 6 & 13 \\
\hline Eggshell & 6 & 2 & 2 & 0 & 5 & 15 \\
\hline
\end{tabular}

P: Penicillin; O: Oxacillin; C: Cefoxitin.

Table 2: Resistance phenotypes of Staphylococcus spp. isolated from egg yolk and eggshell

\begin{tabular}{lcccll}
\hline phenotype & shell & Yolk & Total & Phenotype $\%$ & Resistance \\
\hline A & 4 & 1 & 5 & 17,86 & $\mathrm{P} / \mathrm{O} / \mathrm{C} \mathrm{E} / \mathrm{Cl}$ \\
$\mathrm{B}$ & 2 & 1 & 3 & 10,71 & $\mathrm{P} / \mathrm{O} \mathrm{E} / \mathrm{Cl}$ \\
$\mathrm{C}$ & 2 & 3 & 5 & 17,86 & $\mathrm{P} / \mathrm{O} / \mathrm{C}$ \\
$\mathrm{D}$ & 0 & 1 & 1 & 3,57 & $\mathrm{P} \mathrm{E} / \mathrm{Cl}$ \\
$\mathrm{E}$ & 0 & 1 & 1 & 3,57 & $\mathrm{P} \mathrm{Cl}$ \\
$\mathrm{F}$ & 2 & 0 & 2 & 7,14 & $\mathrm{O} \mathrm{Cl}$ \\
$\mathrm{G}$ & 2 & 6 & 8 & 28,57 & $\mathrm{E}$ \\
$\mathrm{I}$ & 3 & 0 & 3 & 10,71 & - \\
Total & 15 & 13 & 28 & & \\
\hline
\end{tabular}

P: penicillin; O: oxacillin; C: cefoxitin; E: erythromycin; Cl: clindamycin.

Resistance to erythromycin was found in $60.71 \%(\mathrm{n}=$ $17)$ of the isolated bacterial strains, $69.23 \%(n=9)$ in the yolk samples and $53.33 \%(\mathrm{n}=8)$ in the shell samples. Resistance to total clindamycin was $42.86 \%(\mathrm{n}=12)$, with percentage inversion when compared to erythromycin, with $30.77 \%(\mathrm{n}=4)$ of resistance in yolk isolates and $53.33 \%(\mathrm{n}=8)$ eggshell nodes (Fig. 1). Nine strains (32.14\%) MLSb (Staphylococcus with resistance to Macrolides, Lincosamides and Streptogramins) were characterized, phenotypically detected with resistance to both antimicrobials, being three from the yolk and six from shell samples. Erythromycin resistance alone was found in $28.57 \%(\mathrm{n}=8)$ of the samples (6 yolks and two shells) and clindamycin resistance only in $10.71 \%(\mathrm{n}=$ 10) (1 yolk and two shells). Eight bacterial strains showed sensitivity to both antibiotics.

Eight resistance phenotypes were found in the 25 isolated Staphylococcus (Table 2). The most prevalent phenotype comprised eight erythromycin-resistant bacteria (including CoPS), followed by five bacteria 
resistant to all tested antibiotics and five resistant to $\beta$ lactam antibiotics.

The detection of Staphylococcus spp. in eggs of consumption draws attention because, according to (Santana et al., 2010), egg products have already been incriminated in food outbreaks involving staph.

The presence of this microorganism in the shell suggests the need for greater hygienic-sanitary control, aiming at observing aspects such as the shell quality, the washing and disinfection process and the proper storage.

And the fact that MRS strains have been found is fundamental since indiscriminate administration of antimicrobials in feeds as growth promoters accelerate the process of bacterial resistance and the presence of resistant strains in animal products threatens the efficacy of antimicrobials in human (Téo and Oliveira, 2005).

\section{Salmonella spp.}

The 40 dozen samples of surface (shell) and content (yolk) of eggs from free markets in the municipality of Umuarama-PR showed no contamination by Salmonella spp. Samples of eggs without a sanitary inspection, as well as eggs with municipal and federal inspection, were analyzed, all of which were negative for the presence of bacteria of the genus Salmonella. This fact demonstrates that the hygienic-sanitary standard of the birds and the places of laying involved (in all egg yielding properties evaluated) were adequate at the time of this research, regardless of the inspection seal granted or not to the product for the eggs traded at fairs in the municipality of Umuarama-PR, Brazil.

Results similar to this research, confirming the absence of Salmonella spp./25g of the egg sample were also described by (Vaz et al., 2012), in an analysis of 120 eggs from free-range and free-range farms. This research showed a higher degree of contamination by other microorganisms in the "rustic" eggs about the others. Still, none of the categories has detected the presence of Salmonella spp. Other research involving commercial egg analysis showed the absence of the pathogen in the 50 samples analyzed (Silva et al., 2004).

Kottwitz et al. (2008) analyzed 3,000 eggs from a cooperative with commercial posture integration in the state of Paraná, Brazil and obtained isolation of Salmonella spp. in eight of the 30 farms that participated in the research; however, none of the strains were detected from eggs and all samples were negative for the presence of Salmonella Enteritidis (the most important species associated with cases of human salmonellosis in the state of Paraná). Reinforcing this data, another field study indicates that the presence of Salmonella Enteritidis in eggs is considered low, despite the high incidence in lots of laying birds (Barancelli et al., 2012).
More recent studies have also obtained similar results to this research. Gomes Filho et al. (2014) reported the absence of the pathogen Salmonella spp. when analyzing eggs from farms with backyard chickens and eggs from free markets, in Fortaleza-CE, Brazil. The same negative result was reported in research that microbiologically analyzed 280 free-range eggs produced by family farmers in Seropédica, metropolitan region of Rio de Janeiro State, Brazil (Melo et al., 2015).

Unlike the present study, positive results for the presence of Salmonella spp. were found by (Dantas et al., 2006) when performing an experiment with 45 samples of non-inspected white eggs, obtained in Salvador-BA, Brazil, in which seven samples $(15.5 \%)$ were positive for the pathogen. Of these, however, the only one showed contamination of the internal content (yolk) by Salmonella spp. More recent research reports positive results in five $(1.47 \%)$ of the 340 egg samples analyzed from four supermarkets in Jaboticabal-SP, Brazil, but without isolation for Salmonella Enteritidis and Salmonella Typhimurium (Campello, 2012). In a study conducted in the United Kingdom, 1588 pool samples of six eggs from restaurants were analyzed, the Salmonella spp. were found in $6(0.38 \%)$ samples when Salmonella Enteritidis was isolated in five of them (Little et al., 2008).

Still, regarding positive samples (Andrade et al., 2004) conducted a study in Goiânia-GO, Brazil, which randomly collected 816 eggs divided into 272 samples of commercial laying farms and retail outlets. The authors confirmed the presence of Salmonella spp. in five of the analyzed samples, four $(1.48 \%)$ from backyard breeding and one $(0.36 \%)$ from laying farm. These studies that reported the detection of the pathogen in egg samples to point to the importance of research in the area of foodborne diseases, in this case aiming at improving the sanitary and sanitary conditions of farms and establishments, thus collaborating to the food safety of consumers of these products of animal origin.

\section{Conclusion}

It is concluded from this work that the egg, despite having an excellent nutritional value, can be an important vehicle of multiresistant bacterial strains, presenting a risk to humans. Staphylococci are important pathogens of Foodborne Diseases, requiring further epidemiological information regarding outbreaks involving this microorganism. Also, the rational use of antimicrobials is necessary to prevent the emergence of multidrug-resistant strains.

Regarding the absence of Salmonella spp. in all samples analyzed, this work showed a similarity in the sanitary and hygienic standards in the breeding sites 
of these eggs. However, due to the serious problem that this disease represents in a significant part of birds, as well as its zoonotic potential, characterized by the pathogen is one of the most dangerous causes of foodborne illnesses, the epidemiological surveillance of this pathogen is continuously needed, aiming at greater food security.

\section{Author's Contributions}

This section should state the contributions made by each author in the preparation, development and publication of this manuscript.

Ana Claudia Lemes Pavan and Rafaella da Silva: Conception, design and conduction of the study;

Vanessa Kelly Capoia Vignoto: Laboratory support. Marcos Ferrante: Analysis and interpretation of data.

Sheila Rezler Wosiacki and Patrícia Marques Munhoz: Conception, design, drafting the manuscript and critical revision.

All the authors approved the final manuscript.

\section{Ethics}

This article is original and contains unpublished material. The corresponding author confirms that all of the other authors have read and approved the manuscript and no ethical issues involved.

\section{References}

Andrade, M. A., Café, M. B., Jayme, V. S., Rocha, P. T., \& Leandro, N. S. M. (2004). Evaluation of the microbiological quality of eggs commercialized in Goiania, Goias, Brazil. Ci. Anim. Bras. 5, 221-228.

Barancelli, G. V., Martin, J. G. P., \& Porto, E. (2012). Salmonella em ovos: relação entre produção e consumo seguro. Segurança Alimentar e Nutricional, 19(2), 73-82.

Bond, R., \& Loeffler, A. (2012). What's happened to Staphylococcus intermedius? Taxonomic revision and emergence of multi-drug resistance. Journal of Small animal practice, 53(3), 147-154.

Braden, C. R. (2006). Salmonella enterica serotype Enteritidis and eggs: a national epidemic in the United States. Clinical Infectious Diseases, 43(4), 512-517.

Brasil. (1990). Ministério da agricultura, pecuária e abastecimento. Portaria $n^{\circ} 01$ de 21 de fevereiro de 1990. Normas Gerais de Inspeção de Ovos e Derivados. Brasília, BR. www.agricultura.gov.br

Campello, P. L. (2012). Salmonella spp. em ovos brancos para consumo humano.
CLSI (2013). Performance Standards for Antimicrobial Disk and Dilution Susceptibility Tests for Bacteria Isolated from Animals; Approved Standard. VET01-A4. Clinical and Laboratoty Standards Institute, Qayne, PA, ISBN10: 1-56328-880-0.

Dantas, R. A., Souza, A. C. A., \& Régis, L. F. (2006). Estudo da prevalência de Salmonella sp em ovos não inspecionados na cidade de Salvador-Bahia. Reunião Anual da SBPC, Florianópolis, Resumos Eletrônicos...Florianópolis: UFBA. http://www.sbpcnet.org.br/livro/58ra/senior/RESU MOS/resumo_2883.html

Gomes Filho, V. J. R., de Castro Teixeira, R. S., de Souza Lopes, E., de Albuquerque, Á. H., Lima, S. V. G., Horn, R. V., ... \& Cardoso, W. M. (2014). Investigation of Salmonella spp. in backyard chickens (Gallus gallus domesticus) and eggs sold in free markets in the city of Fortaleza, Ceará. Semina: Ciências Agrárias, 35(4), 1855-1864.

Kottwitz, L. B. M., Back, A., Leao, J. A., Alcocer, I., Karan, M., \& Oliveira, T. C. R. M. (2008). Salmonella contamination in an egg production chain of a laying hens integration. Arquivo Brasileiro de Medicina Veterinária e Zootecnia, 60(2), 496-498.

Lacerda, M. J. R. (2011). Microbiologia de ovos comerciais. Seminário apresentado junto à Disciplina Seminários Aplicados do curso de Doutorado do Programa de Pós-Graduação em Ciência Animal da Escola de Veterinária da Universidade Federal de Goiás, 43.

Leal, D. (2011). Práticas adotadas pelo consumidor na compra e utilização do ovo na alimentação (Doctoral dissertation, Universidade de São Paulo).

Little, C. L., Rhoades, J. R., Hucklesby, L., Greenwood, M., Surman-Lee, S., Bolton, F. J., ... \& Threlfall, E. J. (2008). Survey of Salmonella contamination of raw shell eggs used in food service premises in the United Kingdom, 2005 through 2006. Journal of food protection, 71(1), 19-26.

Melo, J. M. M. C., Nascimento, K. O., Barbosa Júnior, J. L., Saldanha, T., \& Barbosa, M. I. M. J. (2015). Diagnosis and microbiological quality of eggs produced by rednecks farmers. Rev. Bras. Ci. Vet. 22, 48-53.

Menezes, L. D. M. (2013). Caracterização microbiológica de ovos de consumo e de carcaças de frangos produzidos no Estado de Minas Gerais.

Oliveira, V. L., \& Taham, T. (2011). Search of Salmonella spp. in eggs commercialized in Federal District. FAZU Revista, 8, 123-130. 
Paiva, J. B., Sterzo, E. V., Ribeiro, S. A., Pereira, E. A., $\&$ Junior, A. B. (2006). Isolamento de Salmonella: comparação das etapas de pré-enriquecimento e enriquecimento direto de amostras de fezes armazenadas por 24 e 96 horas. Arq. Inst. Biol, 73, 263-269.

Santana, E. H. W., Beloti, V., Aragon-Alegro, L. C., \& De Mendonça, M. B. O. C. (2010). Estafilococos em alimentos. Arq. Inst. Biol., São Paulo, 77(3), 545-554.

Shinohara, N. K. S., de Barros, V. B., Jimenez, S. M. C., Machado, E. D. L., Dutra, R. A. F., \& de Lima Filho, J. L. (2008). Salmonella spp, important pathogenic agent transmitted through foodstuffs. Ciencia \& saude coletiva, 13(5), 1675.
Silva, M. C. D. D., Ramalho, L. S., \& Figueiredo, E. T. D. (2004). Salmonella sp em ovos e carcaças de frango in natura comercializadas em Maceió, AL. Hig. alim., 80-84.

Téo, C. R. P. A., \& de Oliveira, T. C. R. M. (2005). Salmonella spp.: The egg as vehicle of transmission and the implications of antimicrobial resistance for public health. Semina: Ciências Agrárias, 26(2), 195-210

Vaz, A. B. S., Yatsuyamagi, S. E., Miyagusku, L., Borba, H., \& Souza, P. A. (2012). Evaluation of the microbiological quality of eggs from breeding type "caipira" farm and commercial production. Hig. Al. 26, 138-142. 